\title{
Characteristics of The Three Cultivar Physiological Growth of Jatropha curcass L. in Two Different Locations Based on Topography
}

\author{
Kovertina Rakhmi Indriana ${ }^{1 *}$, Cucu Suherman ${ }^{1}$, Santi Rosniawaty ${ }^{1}$, Sumadi$^{1}$, Dodi Sukmayana $^{2}$ \\ 'Department of Agriculture, Padjadjaran University, Sumedang, Indonesia \\ ${ }^{2}$ Department of Economic and Business, Winaya Mukti University, Sumedang, Indonesia
}

ARTICLE INFO

Article history:

Received June 10, 2019

Received in revised form October 1, 2020

Accepted October 10, 2020

\section{KEYWORDS:}

growth characteristics, Jatropha cultivars, different altitude places

\begin{abstract}
The purpose of this study was to reveal the sensitivity of cross-location based on topography by giving different FMA consortiums to physiological growth characteristics in three Jatropha curcass L. cultivars. Based on these objectives, the nature of this research is verification. Experiments were carried out in two different places based on topography. The trial time starts from November 2017 to May 2018. Experiments A simple randomized block design (RBD) pattern consisting of fifteen treatment combinations is repeated twice. The experimental results showed that the dose of 10 gr FMA consortium (glomus sp., Acaulospora sp., Gigaspora sp.). With the same spore density gave the best performance of Jatropha plant growth in two different locations based on topography. Observation of chlorophyll content in leaves (age 21, 63, 21 DAP in two locations), plant height (age 21, 63, 21 DAP in two locations), stem diameter (age 21, 63, 21 DAP in two locations) and number of branches secondary (age 21 DAP in two locations) there was a significant effect on the single factor of giving the FMA consortium but there was no interaction between location and treatment.
\end{abstract}

\section{Introduction}

Jatropha has advantages compared to other biofuel-producing plants (oil palm, coconut, palm, corn, soybeans, sugar cane, cassava, etc.) because the high oil content of the seeds (30-40\%) does not compete for other uses, easy to develop and start producing at a relatively short age (3-4 months after planting) and can produce up to around 50 years old. Jatropha has not received any special attention because of the implementation of a very large subsidy policy for fuel (around Rp. 100 trillion in 2010) so that processing castor oil is not profitable. Now is the time for us to take full advantage of the potential of jatropha (Directorate of Annual Plant Cultivation 2007).

Growth of castor plants can be said to be fast and can produce seeds after about $1-3$ years old, depending on the growing environment and the propagation technique both generatively and vegetatively (Heller 1996). The development of seed production must

\footnotetext{
* Corresponding Author

E-mail Address: kovertina.rakhmi.indriana@gmail.com
}

be supported by the procurement of quality seeds that have been selected, in the hope of achieving actual production potential. In order to fulfill quality jatropha seeds, it is necessary to pay attention to two important factors in the supply of seeds, especially for planting material in nurseries, namely the quality and quantity of seeds. Procurement of seeds that are genetically good and timely is a major factor in the success of nurseries (Prihastanti 2010). In jatropha plants, nurseries can be carried out directly or indirectly (Henning 2000; Prajapati and Prajapati 2005) and breeding by generative propagation from seeds is carried out until the age of 2-3 months (Heller 1996; Henning 1998; Henning 2000).

As an annual plant that produces seeds and can live for more than 50 years, Jatropha plants are very sensitive to environmental changes including climate. This results in fluctuating production following changes in the environment. Many Jatropha cultivars exist in Indonesia with variations in the performance of growth, yield and yield of oil. The results of the population selection of Jatropha cultivars conducted by the Pagar Pakuwon Distance Distant Garden in Sukabumi Regency, in 2007 the Pakuwon parent 
garden released $1 \mathrm{P}-2 \mathrm{P}$. The population of IP-2P is the result of selection from IP-1P planted in Pakuwon Sukabumi. Then in 2008 produced an IP-3P cultivar (Improve Population 3 Pakuwon) which was the result of negative mass selection (uprooting and disposing of unwanted plants/not meeting the criteria and maintaining the desired plants in the crop) from IP-2P. The advantages of IP-3P include production potential of 2.3-2.5 tons/ha/year for the first year. And it can reach 8 to 9 tons/ha in the fourth year. This result far exceeds the potential of IP-2P production, which is only around 6.0-6.5 tons/ha in the same year. The oil content of the potential of IP-3P (Pakuwon) is 36 percent (Center for Research and Development of Plantation 2009).

Each land with a topographic height of different regions has different soil chemical properties, such as available levels of $P$ elements in the soil, such as Arbuscular Mycorrhizal Fungi (FMA), which are microbial groups that help release bound $\mathrm{P}$ into available P. FMA also helps plants to absorb nutrients, especially phosphate nutrients (P). Sánchez-Roque (2016) said that The use of AMF in agriculture contributes to improving the nutritional status of the plant, which is reflected in the increased leaf area, root and fruit fresh weight of plants evaluated. Arbuscular mycorrhizal fungi (FMA) can increase water absorption and nutrient elements, protect plants from root pathogens and toxic elements. FMA also produces hormones in the form of cytokines which help plants regulate their growth (Nuhamara 1994; Varma 2008). In addition, FMA plays a role in improving soil structure, increasing nutrient solubility and weathering processes of parent materials. FMA benefits from host plants in the form of carbon compounds from photosynthesis. The relationship that occurs between FMA and plant roots is a symbiotic relationship of mutualism or mutual benefit (Gonzalo and Miguel 2006). Mycorrhizal fungi can utilize plant root exudates as a source of carbon and energy, while plants more easily absorb nutrients, especially nutrient P (Preston 2007 in Suherman 2011).

Jatinangor in Sumedang Regency with an altitude of around $734 \mathrm{~m}$ above sea level (asl), has the type of rainfall $C$ so does Sindanglaut in Cirebon Regency with a height of around $50 \mathrm{~m}$ asl, also has a type of rainfall $\mathrm{C}$ according to Schmidt and Feguson classification (1951). In both places the same soil order, Inceptisol. According to Hadi (2019), the height of different places will be different from the process of plant physiology, this difference will affect plant growth. A cultivar is the same when planted in different environments, the growth and results will be different especially if different cultivars. Different environmental conditions such as climate, temperature, sunlight intensity. Plant growth and development is influenced by differences in the height of planting sites in Sumedang and Cirebon, this is due to differences in biotic and abiotic factors that differ in the two planting sites.

\section{Materials and Methods}

The materials used in these experiments are the seeds within cultivars IP-3P (Improve Population 3 Pakuwon), IP-3A (Improve Population 3 Asembagus), IP-3M (Improve Population 3 Muktiharjo), AMF Consortium (Glomus sp. Gigaspora sp. Acaulospora sp.) (Suherman 2011), the growth medium mix "top soil" + manure + chaff in the ratio $\mathrm{v} / \mathrm{v} 1: 1: 1$, chemical fertilizer used is urea (45\% N), SP-36 ( 36\% P2O5), $\mathrm{KCl}$ (60\% K2O), paranet, plastic, and fungicide Dithane $\mathrm{M}-45$.

The experiment was conducted in the same time in two different places based on differences topography that is the first location as lowland housed in Cirebon (0-50 masl), have orders Inceptisol soil and precipitation type include C (Schmidt and Ferguson 1951)) and a second location as an intermediate plateau housed in Jatinangor (700-750 masl), have orders Inceptisol soil and precipitation type include C (Schmidt and Ferguson 1951). Time trial starting in November 2017 until May 2018.

The experimental design used was a randomized block design (RBD) simple pattern consists of fifteen combination of treatments. Number of treatment combination 15 repeated 3 times, so the number of plots in this trial there were 45 . Placement of treatment in each repetition is done randomly.

$A=$ Cultivars with applications IP-3P Consortium AMF $0 \mathrm{~g} /$ polybag; $\mathrm{B}=\mathrm{IP}-3 \mathrm{~A}$ Cultivars with applications Consortium AMF $0 \mathrm{~g} /$ polybag; $\mathrm{C}=\mathrm{IP}-3 \mathrm{M}$ Cultivars with applications Consortium AMF 0 g/polybag; D = IP-3P Cultivars with AMF Consortium application of $2.5 \mathrm{~g} /$ polybag; $\mathrm{E}=$ Cultivars IP-3A with AMF Consortium application of $2.5 \mathrm{~g} /$ polybag; $\mathrm{F}=$ Cultivars IP-3M with AMF Consortium application of $2.5 \mathrm{~g} /$ polybag; $\mathrm{G}=$ IP-3P Cultivars with applications Consortium AMF $5.0 \mathrm{~g} /$ polybag; $\mathrm{H}=\mathrm{IP}-3 \mathrm{~A}$ Cultivars with applications 
Consortium AMF 5.0 g/polybag; I = IP-3M Cultivars with applications Consortium AMF 5.0 g/polybag; J $=$ IP-3P Cultivars with applications Consortium AMF $7.5 \mathrm{~g} /$ polybag; $\mathrm{K}=\mathrm{IP}-3 \mathrm{~A}$ Cultivars with applications Consortium AMF 7.5 g/polybag; L = IP-3M Cultivars with applications Consortium AMF 7.5 g/polybag; M $=$ Cultivars with applications IP-3P Consortium AMF $10.0 \mathrm{~g} /$ polybag; $\mathrm{N}=\mathrm{IP}-3 \mathrm{~A}$ Cultivars with applications Consortium AMF $10.0 \mathrm{~g} /$ polybag; and $\mathrm{O}=\mathrm{IP}-3 \mathrm{M}$ Cultivars with applications Consortium AMF 10.0 g/polybag. The time needed for this experiment is two weeks for germination and two months in the nursery to get observations of plant responses.

\section{Results}

\subsection{Leaf Chlorophyll}

The results of the calculation of variance analysis on chlorophyll content of leaves, there was no interaction between the dose of FMA consortium and various Jatropha cultivars on leaf chlorophyll content at the age of 21 DAP and 63 DAP in two locations. For more details on the effectiveness of FMA with three Jatropha cultivars on leaf chlorophyll content (CCI) in two different locations based on different altitude places in nurseries can be seen in Table 1.

The results of data analysis on cultivar treatment and FMA dosage significantly affected the chlorophyll content of leaves in each observation period (21 DAP, 63 DAP in Cirebon and 21 DAP in Jatinangor) except at the age of 63 DAP Jatinangor locations are then in Table 1.

Figure 1 shows the activity of measuring the chlorofyll content of leaves in jatropha using a chlorometer measuring instrument. Measurements were made on the surface of jatropha leaves which were dry and clean, and was carried out in the morning.

In each study observation period, data were obtained that at the age of 21 DAP Cirebon location treatment $\mathrm{N}$ showed the highest value and was significantly different from other treatments as well as treatment $\mathrm{N}$ at age 63 DAP in Cirebon location showed the highest value and significantly different from other treatments. At Jatinangor location age 21 DAP treatment $\mathrm{N}$ showed the highest value and significantly different from other treatments, while at

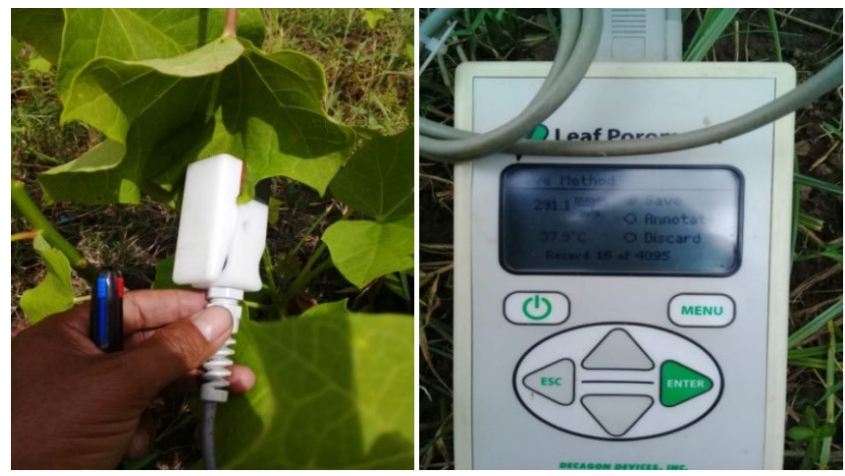

Figure 1. Observation of Jatropha leaf chlorophyll

Table 1. Effectiveness of FMA with three Jatropha cultivars on leaf chlorophyll (CCI) in two different locations based on altitude of different places

\begin{tabular}{|c|c|c|c|c|c|c|c|}
\hline \multicolumn{4}{|c|}{ Location of Cirebon } & \multicolumn{4}{|c|}{ Location of Jatinangor } \\
\hline \multirow{2}{*}{ Cultivar } & \multirow{2}{*}{ Treatment dose FMA (g) } & \multicolumn{2}{|c|}{ Age of plants } & \multirow{2}{*}{ Cultivar } & \multirow{2}{*}{ Treatment dose FMA ( $\mathrm{g}$ ) } & \multicolumn{2}{|c|}{ Age of plants } \\
\hline & & $21 \mathrm{DAP}$ & 63 DAP & & & 21 DAP & $63 \mathrm{DAP}$ \\
\hline \multirow[t]{5}{*}{ IP-3P } & $\mathrm{A}(0)$ & $a b$ & bc & IP-3P & $\mathrm{A}(0)$ & $a b$ & $\mathrm{a}$ \\
\hline & $\mathrm{D}(2.5)$ & $a b$ & $a b$ & & $\mathrm{D}(2.5)$ & $a b$ & $\mathrm{a}$ \\
\hline & G (5.0) & $a b$ & bc & & $G(5.0)$ & $a b$ & $\mathrm{a}$ \\
\hline & $\mathrm{J}(7.5)$ & $a b$ & $a b$ & & $\mathrm{~J}(7.5)$ & $a b$ & $\mathrm{a}$ \\
\hline & $\mathrm{M}(10.0)$ & $a b$ & $\mathrm{~cd}$ & & $\mathrm{M}(10.0)$ & $a b$ & $\mathrm{a}$ \\
\hline \multirow[t]{5}{*}{ IP-3M } & $\mathrm{B}(0)$ & $a b$ & $a b$ & IP-3M & $\mathrm{B}(0)$ & $a b$ & $\mathrm{a}$ \\
\hline & $\mathrm{E}(2.5)$ & $a b$ & $a b$ & & $\mathrm{E}(2.5)$ & $a b$ & $\mathrm{a}$ \\
\hline & $\mathrm{H}(5.0)$ & $\mathrm{a}$ & $a b$ & & $\mathrm{H}(5.0)$ & $a b$ & $\mathrm{a}$ \\
\hline & $\mathrm{K}(7.5)$ & $a b$ & $a b$ & & $\mathrm{~K}(7.5)$ & $\mathrm{a}$ & $\mathrm{a}$ \\
\hline & N 10.0 & c & d & & N 10.0 & b & $\mathrm{a}$ \\
\hline \multirow[t]{5}{*}{$\overline{\mathrm{IP}}-3 \mathrm{~A}$} & $C(0)$ & $a b$ & $a b$ & IP-3A & $C(0)$ & $a b$ & $\mathrm{a}$ \\
\hline & $\mathrm{F}(2.5)$ & $a b$ & $a b$ & & $\mathrm{~F}(2.5)$ & $a b$ & $\mathrm{a}$ \\
\hline & $\mathrm{I}(5.0)$ & $a b$ & $\mathrm{a}$ & & $\mathrm{I}(5.0)$ & $a b$ & a \\
\hline & $\mathrm{L}(7.5)$ & $a b$ & $a b$ & & $\mathrm{~L}(7.5)$ & $a b$ & $\mathrm{a}$ \\
\hline & $\mathrm{O}(10.0)$ & $a b$ & $\mathrm{~cd}$ & & $\mathrm{O}(10.0)$ & $\mathrm{ab}$ & $\mathrm{a}$ \\
\hline
\end{tabular}

The average number followed by the same letter shows that there is no significant difference based on Duncan's Multiple Distance Test at the 5\% level. Uppercase symbols (A to O) on Treatment Dosage FMA column is a combination of treatments between cultivars and the application of FMA doses 
age 63 DAP showed no significant difference between all treatments.

\subsection{Plant Height}

Figure 2 shows the differnce between the growth of jatropha in the nursery at two locations, namely the nursery in Jatinangor and the nursery in Cirebon.

The results of the calculation of variance analysis on plant height, there was no interaction between the dose of the FMA consortium and various Jatropha cultivars on plant height at the age of 21 DAP and 63 DAP in two locations. For more details on the effectiveness of FMA with three Jatropha cultivars on plant height $(\mathrm{cm})$ in two different locations based on different altitude in nurseries can be seen in Table 2 .

The results of data analysis on cultivar treatment and FMA dose significantly affected plant height in each observation period (21 DAP, 63 DAP in Cirebon

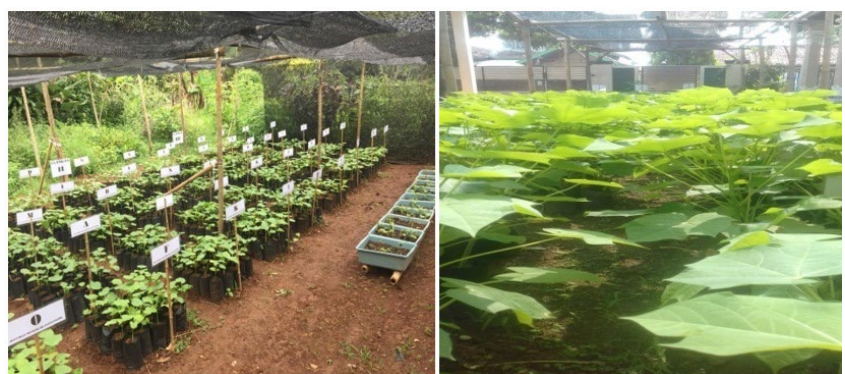

Figure 2. Jatropha plants in nurseries in two locations and 21 DAP in Jatinangor) except at age 63 DAP Jatinangor locations are then presented in Table 2.

In each observation period at the age of 21 DAP CirebonlocationtreatmentMshowed thehighestvalue and significantly different from other treatments, at age 63 DAP Cirebon location in treatment $\mathrm{H}$ showed the highest value and significantly different from other treatments, and at the age of 21 DAP Jatinangor location on treatment $\mathrm{D}, \mathrm{J}, \mathrm{M}$ shows the highest value and is significantly different from other treatments but different from age 63 DAP Jatinangor location shows values that are not significantly different from all treatments.

\subsection{Rod Diameter}

The results of the calculation of variance analysis of stem diameter, there was no interaction between the dose of the FMA consortium and various jatropha cultivars on stem diameter at the age of 21 DAP and 63 DAP in two locations. For more details on the effectiveness of FMA with three jatropha cultivars on stem diameter $(\mathrm{cm})$ in two different locations based on different altitude places in nurseries can be seen in Table 3.

At the age of 21 DAP Cirebon location treatment $\mathrm{N}$ showed the highest value and significantly different from other treatments, at age 63 DAP Cirebon location in treatment $B$ showed the highest value and significantly different from other treatments but not significantly different from treatment C, F, and I. At Jatinangor

Table 2. Effectiveness of FMA with three Jatropha cultivars on plant height $(\mathrm{cm})$ in two different locations based on altitude of different places

\begin{tabular}{|c|c|c|c|c|c|c|c|}
\hline \multicolumn{4}{|c|}{ Location of Cirebon } & \multicolumn{4}{|c|}{ Location of Jatinangor } \\
\hline \multirow{2}{*}{ Cultivar } & \multirow{2}{*}{ Treatment dose FMA (g) } & \multicolumn{2}{|c|}{ Age of plants } & \multirow{2}{*}{ Cultivar } & \multirow{2}{*}{ Treatment dose FMA (g) } & \multicolumn{2}{|c|}{ Age of plants } \\
\hline & & $21 \mathrm{DAP}$ & 63 DAP & & & $21 \mathrm{DAP}$ & 63 DAP \\
\hline \multirow[t]{5}{*}{$\overline{\mathrm{IP}-3 \mathrm{P}}$} & $A(0)$ & $\mathrm{ab}$ & $\mathrm{ab}$ & IP-3P & $A(0)$ & bc & $\mathrm{a}$ \\
\hline & $\mathrm{D}(2.5)$ & $a b$ & a & & $\mathrm{D}(2.5)$ & cd & $\mathrm{a}$ \\
\hline & $G(5.0)$ & $a b$ & $\mathrm{ab}$ & & $G(5.0)$ & $\mathrm{cd}$ & $\mathrm{a}$ \\
\hline & $\mathrm{J}(7.5)$ & $a b$ & $\mathrm{ab}$ & & $\mathrm{J}(7.5)$ & $\mathrm{ab}$ & $a$ \\
\hline & $\mathrm{M}(10.0)$ & b & bc & & $\mathrm{M}(10.0)$ & $\mathrm{e}$ & a \\
\hline \multirow[t]{5}{*}{ IP-3M } & $\mathrm{B}(0)$ & $a b$ & $\mathrm{ab}$ & IP-3M & $\mathrm{B}(0)$ & $\mathrm{bc}$ & $\mathrm{a}$ \\
\hline & $\mathrm{E}(2.5)$ & $a b$ & $\mathrm{ab}$ & & $E(2.5)$ & $a b$ & a \\
\hline & $\mathrm{H}(5.0)$ & $\mathrm{a}$ & $a b$ & & $\mathrm{H}(5.0)$ & $a b$ & $\mathrm{a}$ \\
\hline & $\mathrm{K}(7.5)$ & $\mathrm{ab}$ & $a b$ & & $\mathrm{~K}(7.5)$ & $a$ & $a$ \\
\hline & N 10.0 & $a b$ & c & & N 10.0 & e & a \\
\hline \multirow[t]{5}{*}{$\overline{\mathrm{IP}-3 \mathrm{~A}}$} & $C(0)$ & $\mathrm{ab}$ & $\overline{a b}$ & IP-3A & $C(0)$ & $\mathrm{bc}$ & $a$ \\
\hline & $\mathrm{F}(2.5)$ & $a b$ & $a b$ & & $\mathrm{~F}(2.5)$ & de & $\mathrm{a}$ \\
\hline & I (5.0) & $a b$ & $a b$ & & I (5.0) & de & $a$ \\
\hline & $\mathrm{L}(7.5)$ & $a b$ & $a b$ & & $\mathrm{~L}(7.5)$ & bc & $\mathrm{a}$ \\
\hline & $\mathrm{O}(10.0)$ & $a b$ & $a b$ & & $\mathrm{O}(10.0)$ & e & $a$ \\
\hline
\end{tabular}

The average number followed by the same letter shows that there is no significant difference based on Duncan's Multiple Distance Test at the 5\% level. Uppercase symbols (A to O) on Treatment Dosage FMA column is a combination of treatments between cultivars and the application of FMA doses 
location treatment I showed the highest value and was significantly different from the other treatments and age 63 DAP did not show a difference that was not real.

\subsection{Number of Secondary Branches}

The results of the calculation of variance analysis regarding the number of secondary branches, there was no interaction between the dose of the FMA consortium and various Jatropha cultivars on the number of secondary branches at the age of 21 DAP and 63 DAP in two locations. For more details on the effectiveness of FMA with three Jatropha cultivars on the number of secondary branches (fruits) in two different locations based on different altitudes in nurseries can be seen in Table 4.

Table 3. Effectiveness of FMA with three Jatropha cultivars on rod diameter $(\mathrm{cm})$ in two different locations based on altitude of different places

\begin{tabular}{|c|c|c|c|c|c|c|c|}
\hline \multicolumn{4}{|c|}{ Location of Cirebon } & \multicolumn{4}{|c|}{ Location of Jatinangor } \\
\hline \multirow{2}{*}{ Cultivar } & \multirow{2}{*}{ Treatment dose FMA (g) } & \multicolumn{2}{|c|}{ Age of plants } & \multirow{2}{*}{ Cultivar } & \multirow{2}{*}{ Treatment dose FMA (g) } & \multicolumn{2}{|c|}{ Age of plants } \\
\hline & & $21 \mathrm{DAP}$ & 63 DAP & & & 21 DAP & 63 DAP \\
\hline \multirow[t]{5}{*}{$\overline{\mathrm{IP}-3 \mathrm{P}}$} & $\mathrm{A}(0)$ & $a b$ & $\mathrm{a}$ & IP-3P & $\mathrm{A}(0)$ & $a b$ & $\mathrm{a}$ \\
\hline & $\mathrm{D}(2.5)$ & $\mathrm{a}$ & $a b$ & & $\mathrm{D}(2.5)$ & $a b$ & $\mathrm{a}$ \\
\hline & $G(5.0)$ & $a b$ & bc & & $G(5.0)$ & $\mathrm{a}$ & $\mathrm{a}$ \\
\hline & $\mathrm{J}(7.5)$ & $a b$ & $a b$ & & $\mathrm{~J}(7.5)$ & $a b$ & $\mathrm{a}$ \\
\hline & $\mathrm{M}(10.0)$ & $a b$ & $a b$ & & M (10.0) & $a b$ & $\mathrm{a}$ \\
\hline \multirow[t]{5}{*}{$\overline{\mathrm{IP}-3 \mathrm{M}}$} & $\mathrm{B}(0)$ & $a b$ & $\mathrm{c}$ & IP-3M & $\mathrm{B}(0)$ & $\mathrm{bc}$ & $a$ \\
\hline & $\mathrm{E}(2.5)$ & $a b$ & $a b$ & & $\mathrm{E}(2.5)$ & $a b$ & $\mathrm{a}$ \\
\hline & $\mathrm{H}(5.0)$ & $a b$ & $a b$ & & $\mathrm{H}(5.0)$ & $a b$ & $\mathrm{a}$ \\
\hline & $K(7.5)$ & $a b$ & bc & & $K(7.5)$ & $\mathrm{a}$ & $\mathrm{a}$ \\
\hline & N 10.0 & d & $a b$ & & N 10.0 & $\mathrm{~cd}$ & $\mathrm{a}$ \\
\hline \multirow[t]{5}{*}{$\overline{\mathrm{IP}-3 \mathrm{~A}}$} & $\mathrm{C}(0)$ & $a b$ & c & IP-3A & $\mathrm{C}(0)$ & de & $\mathrm{a}$ \\
\hline & $F(2.5)$ & $\mathrm{cd}$ & c & & $F(2.5)$ & de & $\mathrm{a}$ \\
\hline & I (5.0) & $a b$ & c & & I (5.0) & $\mathrm{e}$ & $\mathrm{a}$ \\
\hline & $\mathrm{L}(7.5)$ & $a b$ & bc & & $\mathrm{L}(7.5)$ & $a b$ & $\mathrm{a}$ \\
\hline & $\mathrm{O}(10.0)$ & $a b$ & $a b$ & & $\mathrm{O}(10.0)$ & $\mathrm{cd}$ & $\mathrm{a}$ \\
\hline
\end{tabular}

The average number followed by the same letter shows that there is no significant difference based on Duncan's Multiple

Distance Test at the 5\% level. Uppercase symbols (A to O) on Treatment Dosage FMA column is a combination of treatments between cultivars and the application of FMA doses

Table 4. Effectiveness of FMA with three Jatropha cultivars on number of secondary branches (sheet) in two different locations based on altitude of different places

\begin{tabular}{|c|c|c|c|c|c|c|c|}
\hline \multicolumn{4}{|c|}{ Location of Cirebon } & \multicolumn{4}{|c|}{ Location of Jatinangor } \\
\hline \multirow{2}{*}{ Cultivar } & \multirow{2}{*}{ Treatment dose FMA (g) } & \multicolumn{2}{|c|}{ Age of plants } & \multirow{2}{*}{ Cultivar } & \multirow{2}{*}{ Treatment dose FMA (g) } & \multicolumn{2}{|c|}{ Age of plants } \\
\hline & & 21 DAP & 63 DAP & & & 21 DAP & $63 \mathrm{DAP}$ \\
\hline \multirow[t]{5}{*}{ IP-3P } & $\mathrm{A}(0)$ & $\mathrm{a}$ & $\mathrm{a}$ & IP-3P & $\mathrm{A}(0)$ & $a b$ & $\mathrm{a}$ \\
\hline & $\mathrm{D}(2.5)$ & $a b$ & $\mathrm{a}$ & & $\mathrm{D}(2.5)$ & $\mathrm{a}$ & $\mathrm{a}$ \\
\hline & G (5.0) & $a b$ & $\mathrm{a}$ & & $G(5.0)$ & $a b$ & $\mathrm{a}$ \\
\hline & $\mathrm{J}(7.5)$ & $a b$ & $\mathrm{a}$ & & $\mathrm{J}(7.5)$ & $a b$ & $\mathrm{a}$ \\
\hline & $\mathrm{M}(10.0)$ & $a b$ & $\mathrm{a}$ & & $\mathrm{M}(10.0)$ & $a b$ & $\mathrm{a}$ \\
\hline \multirow[t]{5}{*}{ IP-3M } & $\mathrm{B}(0)$ & $a b$ & $\mathrm{a}$ & IP-3M & $\mathrm{B}(0)$ & bc & c \\
\hline & $\mathrm{E}(2.5)$ & c & $\mathrm{a}$ & & $\mathrm{E}(2.5)$ & $\mathrm{d}$ & $a b$ \\
\hline & $\mathrm{H}(5.0)$ & $a b$ & $\mathrm{a}$ & & $\mathrm{H}(5.0)$ & bc & bc \\
\hline & $\mathrm{K}(7.5)$ & c & $\mathrm{a}$ & & $\mathrm{K}(7.5)$ & $\mathrm{cd}$ & c \\
\hline & N 10.0 & $a b$ & $\mathrm{a}$ & & N 10.0 & $a b$ & c \\
\hline \multirow[t]{5}{*}{$\overline{\mathrm{IP}}-3 \mathrm{~A}$} & $\mathrm{C}(0)$ & $\mathrm{ab}$ & $\mathrm{a}$ & IP-3A & $\mathrm{C}(0)$ & $a b$ & $\mathrm{a}$ \\
\hline & $\mathrm{F}(2.5)$ & $a b$ & $\mathrm{a}$ & & $\mathrm{F}(2.5)$ & $a b$ & $\mathrm{a}$ \\
\hline & $\mathrm{I}(5.0)$ & $a b$ & $\mathrm{a}$ & & $\mathrm{I}(5.0)$ & $a b$ & $\mathrm{a}$ \\
\hline & $\mathrm{L}(7.5)$ & $a b$ & $\mathrm{a}$ & & $\mathrm{L}(7.5)$ & $a b$ & $\mathrm{a}$ \\
\hline & $\mathrm{O}(10.0)$ & $a b$ & $\mathrm{a}$ & & $\mathrm{O}(10.0)$ & $a b$ & $\mathrm{a}$ \\
\hline
\end{tabular}

The average number followed by the same letter shows that there is no significant difference based on Duncan's Multiple Distance Test at the 5\% level. Uppercase symbols (A to O) on Treatment Dosage FMA column is a combination of treatments between cultivars and the application of FMA doses 
The results of the data analysis on cultivar treatment and FMA dosage significantly affected the number of secondary branches in the observation period of 21 DAP in the two study locations, but at the age of 63 DAP in the two research locations they were not significantly affected.

\subsection{Total Plant Dry Weight}

The results of the calculation of variance analysis regarding the total plant dry weight, there was no interaction between the dose of the FMA consortium and various Jatropha cultivars on total plant dry weight at the age of 21 DAP and 63 DAP in two locations. For more details on the effectiveness of FMA with three Jatropha cultivars on the total plant dry weight $(\mathrm{g})$ in two different locations based on different altitudes in nurseries can be seen in Table 5 .

The results of the data analysis on cultivar treatment and FMA dosage at the ages of 21 and 63 DAP in the two same-time locations have an effect and give significantly different results on the total dry weight of plants.

\section{Discussion}

Leaf chlorophyll content is obtained from the third Jatropha leaf which is active in photosynthesis. Leaves are indicators of growth as well as parameters that can describe the ability of plants to carry out photosynthetic activities. There is a real difference between cultivars because each distance cultivars have different characteristics. The more chlorophyll content shows more green leaves. Leaves are used by plants to carry out photosynthesis. The greener leaves the more chlorophyll content, the higher the photosynthesis rate. Cultivary treatments and FMA doses significantly affected the chlorophyll content of leaves in each observation period (21 DAP, 63 DAP in Cirebon and 21 DAP in jatinangor) except at age 63 hst the location of Jatinangor. fma administration can increase plant photosynthate supply. Mathur and Vyas (2000) suggest that the presence of JMA inoculation canincrease theaccumulation of aminoacids, proteins, chlorophyll and sugar content compared to nonmycorrhizal plants. Increased phosphorus in plants

Table 5. Effectiveness of FMA with three Jatropha cultivars on total plant dry weight $(\mathrm{g})$ in two different locations based on altitude of different places

\begin{tabular}{|c|c|c|c|c|c|c|c|}
\hline \multicolumn{4}{|c|}{ Location of Cirebon } & \multicolumn{4}{|c|}{ Location of Jatinangor } \\
\hline \multirow{2}{*}{ Cultivar } & \multirow{2}{*}{ Treatment dose FMA (g) } & \multicolumn{2}{|c|}{ Age of plants } & \multirow{2}{*}{ Cultivar } & \multirow{2}{*}{ Treatment dose FMA (g) } & \multicolumn{2}{|c|}{ Age of plants } \\
\hline & & $21 \mathrm{DAP}$ & 63 DAP & & & 21 DAP & 63 DAP \\
\hline \multirow[t]{5}{*}{$\overline{\mathrm{IP}}-3 \mathrm{P}$} & 0 & $\mathrm{a}$ & $\mathrm{a}$ & IP-3P & 0 & $\mathrm{ab}$ & $\mathrm{ab}$ \\
\hline & 2.5 & $a b$ & $\mathrm{a}$ & & 2.5 & $a b$ & $\mathrm{ab}$ \\
\hline & 5.0 & $a b$ & a & & 5.0 & $a b$ & $\mathrm{ab}$ \\
\hline & 7.5 & $\mathrm{ab}$ & $\mathrm{a}$ & & 7.5 & $a b$ & $\mathrm{ab}$ \\
\hline & 10.0 & bc & $\mathrm{a}$ & & 10.0 & b & $\mathrm{cd}$ \\
\hline \multirow[t]{5}{*}{ IP-3M } & 0 & $\mathrm{ab}$ & $\mathrm{a}$ & IP-3M & 0 & $\overline{a b}$ & $\mathrm{ab}$ \\
\hline & 2.5 & $a b$ & a & & 2.5 & $\mathrm{a}$ & $\mathrm{ab}$ \\
\hline & 5.0 & bc & a & & 5.0 & $a b$ & a \\
\hline & 7.5 & $a b$ & a & & 7.5 & $a b$ & bc \\
\hline & 10.0 & c & b & & 10.0 & b & d \\
\hline \multirow[t]{5}{*}{$\overline{\mathrm{IP}-3 \mathrm{~A}}$} & 0 & $a b$ & $a$ & IP-3A & 0 & $\overline{a b}$ & $a b$ \\
\hline & 2.5 & $a b$ & $\mathrm{a}$ & & 2.5 & $a b$ & $\mathrm{ab}$ \\
\hline & 5.0 & $a b$ & $\mathrm{a}$ & & 5.0 & $a b$ & $a b$ \\
\hline & 7.5 & $a b$ & a & & 7.5 & $a b$ & $a b$ \\
\hline & 10.0 & bc & $a$ & & 10.0 & b & $\mathrm{cd}$ \\
\hline
\end{tabular}

The average number followed by the same letter shows that there is no significant difference based on Duncan's Multiple Distance Test at the 5\% level. Uppercase symbols (A to O) on Treatment Dosage FMA column is a combination of treatments between cultivars and the application of FMA doses 
affects photosynthetic activity, because the higher photosynthetic rate in plants that have mycorrhiza because of its relationship with increasing nutrient P (Guillemin et al. 1996). According to Twn (2000) mycorrhizal infections in plants can increase nutrient translocation to the upper part of the plant so that photosynthesis increases and the use of assimilates in the canopy and photosynthate supply increases from leaves to roots. As a result, mycorrhiza plants have higher biomass than without mycorrhiza.

The response of the growth of Jatropha seedlings which was inoculated with arbuscular mycorrhizal fungi (FMA) was higher than that of seeds without FMA, this study showed that Jatropha curcas that were given FMA isolates showed better growth in all observed growing organs (roots, leaves, and stems ) in both locations. FMA which infects the root system of host plants will produce intricate external hyphae to produce optimal length and volume of external hyphae, as a result of plants infected with mycorrhizae can increase their ability to absorb nutrients and water (Sieverding 1991). The administration of mycorrhizal isolates from Glomus sp., Acaulospora sp., Gigaspora sp., Showed different levels of effectiveness of FMA in two different locations. Mixed mycorrhizal isolates were more effective than single isolates as indicated by better plant growth in all tested Jatropha cultivars. This is because each type of FMA has advantages and disadvantages, so that if you can synergize it will produce better results. In addition, each isolate also has a different preference for exudates issued by Jatropha seedlings. The results of this study are in accordance with Delvian's(2003)study which showed that a mixture of 2 isolates and 3 isolates tended to be more effective than single isolates in increasing the growth of lamtorogung (Leucaena leucacephala) plants. The results of other studies also showed that the growth of oil palm seedlings given a mixture of 3 FMA isolates turned out to produce higher plant heights than plants that were given a single isolate on the PMK soil former rubber plantation, former forest FMD, and former forest peat soil.

At the age of 21 DAP Cirebon location treatment $\mathrm{N}$ showed the highest value and significantly different from other treatments, at age 63 DAP Cirebon location in treatment $B$ showed the highest value and significantly different from other treatments but not significantly different from treatment C, F, and I. ability mycorrhizae in helping the roots to absorb nutrients, where external hyphae from mycorrhizae that extend into the soil will play a role in helping plant root systems. Nutrients absorbed by plant roots will be used to stimulate photosynthesis in the leaves. The results of photosynthesis will be translocated throughout parts of the plant for plant growth and development (Gardner et al. 1991). At Jatinangor location treatment I showed the highest value with the other treatment and age 63 DAP did not show a non-significant difference, this was due to the mycorrhizal given to the soil had not been able to function optimally in assisting the roots in the absorption of the given P element. The development of stem diameter depends on the availability of nutrients in the soil, especially P which plays a role in the division and development of plant cells. The same thing is explained by Lakitan (2004) which states that phosphorus is involved in the division and formation of root cells and plant stems.

The cultivar treatment and FMA dose significantly affected the number of secondary branches in the observation period of 21 DAP in the two study locations, but at the age of 63 DAP in both locations.

There is a significant influence on the total dry weight of plants, it is suspected that the treatment dose of the consortium FMA can influence the increase in photosynthate. Dry weight is an indication of the success of plant growth because dry weight is an indication of the results of clean photosynthesis that can be deposited after the water content is dried. Plant growth is indicated by the addition of dry weight size that reflects the increase in protoplasm because the size and number of cells increases (Prayudyaningsih 2008). Dry weights also show the ability of plants to take nutrients to support their growth (Harjadi 2002).

\section{Conclusion}

The experimental results showed that the dose of 10 gr FMA consortium (glomus sp., Acaulospora sp., Gigaspora sp.) with the same spore density gave the best performance of Jatropha plant growth in two different locations based on topography. Observation of chlorophyll content in leaves (age 21, 63, 21 DAP in two locations), plant height (age 21, 63, 21 DAP in two locations), stem diameter (age 21, 63, 21 DAP in two locations), total plant dry weight (age 21, 63, 21 DAP in two locations) and number of branches secondary (age 21 DAP in two locations) there was a significant effect on the single factor of giving the FMA 
consortium but there was no interaction between location and treatment. Thus it can be concluded that the best application of FMA doses that affect plant growth is 10 gr FMA.

From the results achieved, the researchers suggested that giving doses of FMA as much as 0 gram was not recommended because it did not show unreal results for mycorrhizal colonization or phosphatease compounds produced by the mycorrhiza. Researchers suggest adding genus from FMA because it is suspected that the addition of the FMA genus can increase growth, yield components, yield, oil yield and because of the elasticity of jatropha biodiesel.

\section{Acknowledgements}

LPDP (Lembaga Pengelolaan Dana Pendidikan) which has provided an opportunity for writers to obtain a 2016 BUDI-DN doctoral education scholarship and has provided a Dissertation Research fund. DIKTI The Directorate General of Higher Education of the Republic of Indonesia and DRPM (Direktorat Riset dan Pengabdian Masyarakat). Chancellor of the University of Winaya Mukti (UNWIM) which always gives encouragement and motivation to the lecturers to implement the tridharma of higher education. Faculty of Agriculture, Padjadjaran University (UNPAD). The Chairperson of the Winaya Mukti University LPPM who tirelessly facilitated this research. Colleagues at Winaya Mukti University Faculty of Agriculture who helped in carrying out this research.

\section{References}

Delvian. 2003. Diversity of arbuscular mycorrhizal fungi (CMA) in coastal forests and their potential uses, case study in the Leuweung Sancang Nature Reserve Forest in Garut Regency, West Java [Dissertation]. Bogor, Indonesia: IPB University.

Directorate of Annual Plant Cultivation. 2007. Guidelines for Cultivating Jatropha Curcas. Available at: http:// ditjenbun.deptan.go.id/tahunanbun/tahunan. [Date accessed: 12 June 2019]

Gardner FP et al. 1991. Cultivation Physiology. Jakarta: UI Press.

Gonzalo BE, Miguel A. 2006. Mycorrhizal Ecological an Alternative for Sustainable Agriculture. Available at: http://www.micorhizal.html [Date accessed: 12 June 2019]

Guillemin JP et al. 1996. Influence of Arbuscular and Ericoid Mycorrhiza Formation on the Level of Photosynthetic Pigments in Host Plants. European Commission Directorate-General XII, Science, Research and Development.

Hadi RA. 2019. Keragaan pertumbuhan tanaman jarak pagar (Jatropha curcass) di pembibitan akibat pemberian mikoriza di dua lokasi berbeda berdasarkan ketinggian tempat. Jurnal Pertanian 10:43-51.
Harjadi S. 2002. Introduction to Agronomy. Jakarta: Gramedia Main Library.

Heller J. 1996. Physic Nut, Jatropha curcas L. Promoting the Conservation and Use of Underutilized Crops I. Rome: International Genetic Resouurces Institute.

Henning R. 1998. Combating Desertification: The Jatropha Project of Mali, West Africa. Aridland No.40, Fall/ Winter 1996. The CCD, Part I: Africa and The Mediterranean. Available at: http://ag.arizona.edu/ OALS/ALN/aln40/jatropha.html [Date accessed: 25 January 2018]

Henning R. 2000. The Jatropha Manual: A Guide to the Integrated Exploitation of the Jatropha Plant in Zambia. Bagani GbR. Produced for GTZ. GTZ-ASIPSupport-Project Southern Province, Choma. Available at: http://www.jatropha.de/documents/jcl-manual. pdf [Date accessed: 15 June 2019]

Lakitan B. 2004. Basics of Plant Physiology. Jakarta: PT Raja Grafindo Persada.

Mathur N, Vyas A. 2000. Influence of arbuscular mycorrhizae on biomass production, nutrient uptake and physiological changes in Ziziphus mauritiana Lam. under water stress. Journal of Arid Environments 45:191-195.

Nuhamara ST. 1994. Peranan mikoriza untuk reklamasi lahan kritis. In: Program Pelatihan Biologi dan Bioteknologi Mikoriza. Bogor: Institut Pertanian Bogor.

Prajapati ND, Prajapati. 2005. A Handbook of Jatropha curcas Linn. (Physic Nut). Available at: www.fact-fuels.org [Date accessed: 14 June 2019]

Prayudyaningsih R. 2008. Acceleration of Growth of the Bitti Plant (Vitex cofasuss Reinw) with the Application of Arbuscular Mycorrhoea Function (FMI). Makassar: Forestry Research Institute.

Prihastanti E. 2010. Nursery Jatropha curcass on soil types and addition of different composts. Anatomy and Physiology Bulletin 18:....... .

Preston S. 2007. Soil Alternative Amandements. NCAT Agriclture Specialist. National Sustainable Agricucture Information Service. Attra Publication. Available at: http://www.attra.ncat.org/attra-pub/PDF/altsoil.pdf. [Date accessed: 3 August 2018]

Sánchez-Roque Y et al. 2016. Effect of arbuscular mycorrhizal fungi in the development of cultivars of chili. Int JAdv Agric Res 4:10-15.

Schmidt FH, Ferguson JHA. 1951. Rainfall Types Based on Wet and Dry Periods for Indonesia with Western New Guinea. Verhandelingen NO. 42. Jakarta: Ministry of Transportation. Djawatan Meteorology and Geophysics.

Sieverding E. 1991. Vesicular Arbuscular Mycorrhiza Management in Tropical Agrosystems. Eschborn: Deutsche Gessellschaft fur Technische Zusammenarbeit (GTZ).

Suherman C. 2011. Increased Growth, Results And Oil Yield (Jatropha curcas Linn) Through Application of Mycorrhizal Fungi Fungi and Phosphate Fertilizer In Inceptisol Jatinangor [Dissertation]. Bandung, Indonesia: Padjadjaran University.

Twn CR. 2000. Study of the Effectiveness of Endomycoriza in Teak Nurseries (Tectona grandis Linn F.). Bogor: Forest Research and Development Center and Nature Conservation.

Varma A. 2008. Mycorrhiza: State of the Art, Genetic and Molecular Biology, Eco-Function, Biotechnology, EcoPhysiology, Structure and Systematics. India: Springer. 